\title{
The Evolution of Modern Architecture Style in Context of Postcolonial Campus
}

\section{Mean Pisei ${ }^{1}$, Ikaputra ${ }^{2}$}

'Student of Master of Architecture, Department of Architecture and Planning, Faculty of Engineering, Universitas Gadjah Mada, Yogyakarta, Indonesia 2Professor of Architecture at Department of Architecture and Planning, Faculty of Engineering, Universitas Gadjah Mada, Yogyakarta, Indonesia
Article History

Received : 18 January 2021

Accepted : 06 April 2021

Published : 24 April 2021

\begin{abstract}
The development of Indonesian architectures in the post-colonial era were the phase of new experiment and ideas that gave a birth to the awareness and spirit of exploring nation identity. Universitas Gadjah Mada is recognized as a post-colonial and the oldest national campus founded in 1949 in Yogyakarta. This paper aims to investigate the evolution of modern movement in the sense of campus architecture. Case study material is drawn mainly from post-colonial campus architecture at the central zone of Universitas Gadjah Mada. The method used is a qualitative methodology in which data is obtained from literature reviews and field observations. The development of modern architecture theories and styles have been studied through the case study. The finding of this study showed that socio-political transition of the old order, the new order, and present era, and also personal vision of the architect contributed to the production of modern architectures.
\end{abstract}

Keywords: evolution of style; modernism; modern movement; post-colonial campus

\section{Introduction}

The arrival of modern architecture is thought to have occurred in the nineteenth century that coinciding with the industrial revolution. Following the emergence of industrial production, this design trend is interested in functionalist planning, modern construction materials, and the implementation of existing new technologies. And throughout modern architecture's history, there have been some changes in architectural perception and aesthetic building theory. As a result, diverse opinions on Modern Architecture's aesthetics arose, resulting in various architectural styles (Ali, 2018). In the post-colonial sense, modern architecture was not the architectural production that focused more on modern material and technology to convey modernity but paid more attention to non-physical forms

Correspondence: Mean Pisei

Department of Architecture and Planning, Faculty of Engineering, Universitas Gadjah Mada, Yogyakarta, Indonesia

E-mail: piseimean18@gmail.com that shape the history of construction designs, their meaning, and political ideology (Abdu \& Syahid, 2018).

In Indonesia's case, the post-colonial era was the time of modern movement that interpreted the idea into the creation of a new architecture style. It was designed for the identity of Indonesian architecture that is modern and no longer neither adopted nor reflected the Dutch colonial style (Abdu \& Syahid, 2018). Indonesia achieves this modern architecture development goal by blending the traditional and modern style with adaptation to local climate, material, and technology at the time. For instance, there are plenty of modern function buildings such as government offices, campuses, hospitals, markets, and others designed in the shape of Indonesia's indigenous architecture (Ardiyanto et al., 2014). Therefore, the post-colonial era's architecture development is used as a tool for political leaders to transform their ideology on how to lead and modernize the country. Hence, the first and the second Indonesian presidents showed the prosperity of country development under their political era through architecture growth. It's appropriate to say, in other words, 
that a political leader who is the instructor and architect who is the actor both are the key to the revolution (Hanum, Lukito \& Kurniawan, 2020). The new revolution in Indonesia is a spirit of transition in terms of democracy and liberty, balancing the relationship with the historical elements and taking inspiration from international modernity (Abdu \& Syahid, 2018). Consequently, Indonesia's urban and architectural growth was a significant stage of development in the 20th century after the Independent. However, as stated earlier, in the post-colonial era, the first and the second president desired to construct nation buildings. In the current era, the architecture of this country is undergoing a drastic transition to Western hegemony in architectural scenes that question regionalism and nationalism (Wiryomartono, 2013).

In the post-colonial era, the infrastructure development focused on establishing public buildings such as monumental buildings, offices, markets, campuses, etc. The establishment of a national university in that period is seen as an image of a deliberate decolonization movement and understanding the related problems (Peters, 2019). On the other hand, the history of universities and their campuses shows two things: on the one hand, the individual variety of these institutions, each having its unique personality, context, and ethos; on the other hand, the common patterns and typologies whose evolution over time leaves traces in the physical fabric of universities. Thus, the architecture and landscape in campus development are becoming an image of cultural transition (Hebbert, 2018). Therefore, it is very interesting to discuss the creation of a postcolonial university. Universitas Gadjah Mada (UGM) was raised as a case study.

The UGM campus was a national campus that was established in the post-colonial era. It was founded in 1949 in Yogyakarta, and the first campus building development was taken place in the central zone. The establishing of this campus made the first move to the Central Zone. The development of campus building in this zone took more than 60 years and experiencing the political shift of Old Order, New Order, then and now era, between 1951 and 2012. The first building in the central zone was the central office which developed in the political era of President Sukarno. That era was later named the Old Order. The architect of this first building was directly appointed by President Sukarno and also being instructed to design a campus building that reflects his political ideology (Ismudiyanto; Santoso, 2016). In the following political era, the New Order, then and now political's era, some campus buildings were designed by other architects with different design approaches. Each architect designed their building carefully to interconnected the political perception and maintain a balance between modernity, locality, and identity. These buildings are designed in modern architecture approach but adopted a different design principle and produced different styles. However, these buildings were presenting their arrival with different faces. Still, they moved on the same philosophy, which aims to build a campus identity and develop new architecture following the architecture trend.

The purpose of this paper is to investigate the evolution of modern architecture style in the context of campus design with a case study of the campus of Universitas Gadjah Mada (UGM), specifically in the central zone. It is anticipated that this research will contribute particularly to the field of architecture concerning the evolution of modern architecture style in the context of campus development. The evolution of building style with a specific timeline will be drawn as a result of the case study. Besides, the overview of the choice of styles, the personal preference of the architect, and interpretation of political influence will be studied. Furthermore, this research has contributed to the study of Heritage and Conversation as a precedent study of post-colonial architecture in Indonesia.

\section{Literature Review}

\section{The Rise of The Post-Colonial Campus}

The rise of post-colonial campus is formed under directions to reaffirm cultural values and identity by implementing two methods. One is to reaffirm the civilizational culture of the precolonial university that under colonized by a Western modernist. Meanwhile, the other comes with the first experimentation of the indigenous university to protect, adapt and develop indigenous values. In both forms, the inspiration comes in part from an interpretation and analysis of Western colonization and the different ways in which universities of European influence were a means of social control and knowledge production. As a consequence, pre- 
colonial universities have been developed to be global institutions (Peters, 2019).

The orientalism that Foucault's exclusion strategy offers a general theoretical model for examining and interpreting the university as a locus for cultural influence and power/ knowledge circulation. Furthermore, a postcolonial university seeks to decolonize the university, its curricula, and its modes of organization and administration through a practice that rehabilitates traditional knowledge at the same time while opposing the new round of globalization and the university discourse of the world-class that universalizes neoliberal experience. The return to the local should inspire the means at any stage of creativity and growth to promote openness to the colonial history of the past and openness to the future that does not prevent new ways of thinking and doing. In this sense, at the beginning of independence as well as at the end of colonialization, the post-colonial university is not merely an institution of the university, but an attempt to rethink the institution of the university that distinguishes it from its colonial forms and opens up new possibilities of becoming another type of institution (Peters, 2019). To discuss this argument, the Universitas Gadjah Mada was chosen as a case study observed on the establishment of post-colonial campus through the focus of architecture development.

\section{The Movement of Modern Architecture in Indonesia}

Historically Indonesian modern architecture has taken place since the end of the Dutch colonial era. It started in the post-colonial time when was a transition of modern and local architecture. And it continued up to the contemporary era. The term "modern" in the architecture context has multiple purposes to fulfil the political culture and social realms (Abdu \& Syahid, 2018). Modernity has been viewed by Abidin Kusno as an architectural discourse that is driven by the modern idea. It does not always manifest modernity through physical aspects such as building function, style, technology, and material types, but it focuses on non-physical aspects. The nonphysical elements form the background of the building designs, philosophy, political context, and the interpretation of modern culture in a post-colonial context (Kusno, 2000). In addition to modernity, Abidin Kusno claimed that this architectural discourse was linked to a movement. He agrees with President Soekarno's idea that the ideology of modern movement has the intention to break through from the past and claimed independence and freedom in the present time onward (Kusno, 2012). Modern architecture took inspiration from international modernity instead of following the architectural colonial trace (Abdu \& Syahid,

Diagram 1. Timeline of Indonesian architecture design inspiration

Source: Author self-organized, 2020. Cited from (Purwaningrum, 2017)

TIMELINE OF INDONESIAN ARCHITECTURE INSPIRATION

\begin{tabular}{|c|c|c|c|c|c|}
\hline \multicolumn{2}{|c|}{$\begin{array}{l}2^{\mathrm{TH}} \text { CENTURY } \\
(1920-1940)\end{array}$} & $\begin{array}{c}20^{\mathrm{TH}} \text { CENTURY } \\
(1945-1967)\end{array}$ & $\begin{array}{l}20^{\mathrm{TH}} \text { CENTURY } \\
(1967,1998)\end{array}$ & \multicolumn{2}{|c|}{$21^{\text {ST }}$ CENTURY-PRESENT } \\
\hline $\begin{array}{r}\text { END C } \\
\text { COLO } \\
\text { EARLY IN } \\
\text { (NATIO) } \\
\text { SU) } \\
\text { Synthesiz } \\
\text { East (lo } \\
\text { cultu } \\
\text { (mo }\end{array}$ & $\begin{array}{l}\text { DUTCH } \\
\text { AL ERA } \\
\text { PENDENCE } \\
\text { LEADER } \\
\text { RNO) } \\
\text { ne culture of } \\
\text { ity) \& the } \\
\text { f West } \\
\text { nism) }\end{array}$ & $\begin{array}{c}\text { POST COLONIAL } \\
\text { ERA } \\
\text { INDEPENDENCE } \\
\text { (PRESIDENT SUKARNO) } \\
-\quad \text { Indonesian Independence } \\
-\quad \text { New translation Indonesian } \\
\text { Context and Identity }\end{array}$ & $\begin{array}{c}\text { POST COLONIAL } \\
\text { ERA } \\
\text { POST INDEPENDENCE } \\
\text { (PRESIDENT SUHARTO) } \\
\text { - New translation } \\
\text { - Indonesian Context and } \\
\text { Identity } \\
\text { - } \quad \text { Recapture Indonesian } \\
\text { Identity } \\
\end{array}$ & \multicolumn{2}{|c|}{$\begin{array}{l}\text { CONTEMPORARY } \\
\text { ERA } \\
\text { POST INDEPENDENCE } \\
\text { (THEN AND NOW) }\end{array}$} \\
\hline DESIGN & PPROACH & DESIGN APPROACH & DESIGN APPROACH & \multicolumn{2}{|c|}{ DESIGN APPROACH } \\
\hline $\begin{array}{c}\text { Indonesian } \\
\text { cultural } \\
\text { aspect }\end{array}$ & $\begin{array}{l}\text { Interpretation } \\
\text { of Tropical } \\
\text { architecture }\end{array}$ & $\begin{array}{l}\text {-Adapting paradigm of } \\
\text { modernism, functionalism, } \\
\text { reductionism to make a } \\
\text { Nation character building. } \\
\text {-Incorporating modern } \\
\text { architecture in Indonesian- } \\
\text { ness architecture. } \\
\text {-Escape from all forms of } \\
\text { Colonial influences. }\end{array}$ & $\begin{array}{l}\text {-Use the concept of } \\
\text { traditional architecture to } \\
\text { recapture Indonesia identity. } \\
\text {-Use the concept of } \\
\text { traditional architecture to } \\
\text { adapt in modern buildings } \\
\text { design. }\end{array}$ & $\begin{array}{l}\text { Adapting } \\
\text { Vernacular } \\
\text { architecture }\end{array}$ & $\begin{array}{l}\text { Minimalist } \\
\text { style }\end{array}$ \\
\hline
\end{tabular}


2018). Therefore a modern architecture that comes in the post-colonial era has been driven by political influence and government.

During the early independent declaration of sovereignty in the Indonesian post-colonial era, Indonesia's first and second presidents took architectural development seriously as a tool for nation-building. Both of them, however, have the same objective of building the nationality and identity of Indonesian. They had different leading ways to the development of architecture. In the first phase of the postcolonial period, the architecture development was under the control of Indonesia's first president Sukarno (1945-1967). He intends to leave from the colonial trace of architectural style and create a nation-state's new independent identity after colonialism. During the post-colonial Old Order of Sukarno, the new architectures were embodied by the order of adoption model in the approach to design for modernism, functionalism, and reductionism (Purwaningrum, 2017). Therefore the postcolonial architecture design paradigm of modern architecture focuses more on function and simplicity. Later during the post-colonial New Order of Sukarto (1967-1998), who was the second president of Indonesia, it was the time of rebirth of traditional architecture in modern architecture development. The architectures have been developed in a parallel direction to vernacular architecture that promotes the awareness of traditional architecture, local culture, and philosophy. Therefore architectural approach seeks to combine conventional architectural typology and adapted it to some theory of modern design. His goal is to foster Indonesian architecture and identity (Purwaningrum, 2017). Within the political shift that leads to a contradiction between the Old Order and the New Order, Abidin Kusno made a post-colonial critic to the architecture movement that there is a transition from national to regional approach (Kusno, 2000).

After 1998, President Suharto's era is over, and start a new era called as Then and Now era. The architecture development also changed direction. The minimalist architecture trend in contemporary architecture has been introduced. Unlike the previous political era, the concept design in the contemporary era is free from political power but inspired by the client's intention and the personal inclination of an architect. And somehow, contemporary Indonesian architecture is an abundance of locality and place identity. The contemporary architects of Indonesia tend to adopt modern trends expressed in both public and residential buildings. Without considering meaning and identity, or less, the contemporary architect has begun to bring modern style into its architecture. The critic appears, after all, on many buildings and so forth. Architects, academics, educators, and decision-makers have now begun to reconsider the adequacy of modern style in the Indonesian context. In constructing a building that not only provides a signature on the building but also makes a greater contribution to society, this order gives contemporary architects a challenge. In copying with the Indonesian context, most architects strive to combine modernism with localism, accepting both the temporal context and cultural heritage (Purwaningrum, 2017). Due to this phenomenon, Indonesian architect scholar Y.B. Mangunwijaya once said Indonesian architecture has become a hybrid architecture of modern and traditional (Loanoto \& Hidayahtun, 2019).

\section{The Variety of Modern Styles}

The birth of modern architecture was thought to begin in the 19th century with the industrial revolution and the subsequent rise of mass manufacturing, which sparked a general dislike of historicism, interest in functionalist planning, modern building materials, and the use of emerging new technologies. Modern architecture can be divided into two eras based on their aesthetics: a) Early modern architecture and b) Late modern architecture (Nia \& Rahbarianyazd, 2020)

Early modern architecture is classified into three categories: technical rationalism or rationalist tendencies; architectural formalism or formalism tendencies; functional tendencies. Rationalism emphasizes ideal proportions and geometric shapes, as well as pure approaches to form and material design. Formalism is a term that refers to design that is based on form theory. The building's form became important to the modern aesthetic within this context. The foremost styles of formalism tendencies in the early modern era including Arts and Crafts movement (1860-1910), Beaux-Arts Architecture (1885-1945), Art Nouveau (18901910), Gothic Revival Neo-Gothic (1905- 
1930), Expressionism (1905-1925), Futurism (1909-1945), Constructivism (1914-1932), De Stijl (1917-1931), Art Deco (1925-1945), Art Moderne Machine Age Architecture (19351950). In the second half of the twentieth century, functionalism was a form of architecture that tried to balance aesthetic and functionality. Functionalism conjures up images of space's selflessness, in which case a space designated for one function can be retrofitted for another. As a result, the room can be used for several purposes. The main schools of functionalist architecture are the Chicago school (18751925), Bauhaus school (1919-1933), and Prier school (1905-1925) (Nia \& Rahbarianyazd, 2020).

The late modern was the most common style between the post-World War II era and the early 1970s. The four major architectural styles in last modern are including International style (1920-1965), Brutalism, Minimalism (the 1960s-1970s), and Organic architecture. International style is the architecture style that appears in the $19^{\text {th }}$ and $20^{\text {th }}$ century to against the historicist and Art Nouveau styles. On the other hand, Brutalism was an architecture that respects the nature-ness of the construction material and building structure. Meanwhile, Organic architecture is based on the idea that a structure and its surroundings are the same. For example, the Organic architecture theory has been proposed by architect Frank Lloyd Wright. He tried to conceptualize the idea that a building emerges from its natural setting, nature's symbiotic ordering structures are reflected in organic architecture (Wright, 1954). Finally, Minimalism architecture emerged as the later trend to the post-World War II Western Arts. It was most noticeable in the 1960s and early 1970s American visual arts. Minimalism is a reductive philosophy of architecture that preys on modernism. Design elements within this philosophy project a sense of simplicity (Nia \& Rahbarianyazd, 2020).

There are plenty of architectural styles which has been developed at a specific time. Some of them are remaining a long life since the birth of its style up to the present time. Meanwhile, some of the styles have only a short life. Therefore, throughout architectural history, the arrival of each architectural style appears for its own sake of architecture trends and tells stories about how humans survive their daily lives from time to time (James-Chakraborty, 2014).

\section{Methodology}

As a research object located in the central zone of UGM, the research approach used in this analysis is a qualitative method with more focus on campus architectures. The research method is using qualitative research and analyzes the character of architecture base on a typology approach. The unit observation of this research is limited to the building façade study. This study adopted both library research and field research. Also, this study will analyze the data based on content analysis with the descriptive method.

\section{Result and Discussion}

\section{The Development History of The UGM Campus in The Central Area}

In Yogyakarta, Universitas Gadjah Mada (UGM) is recognized as the first post-colonial campus architecture and the oldest national Indonesian university created in the mid-20 th century. Historically, the UGM has been known under Balai Perguruan Gadjah Mada, supported by the Government of the Republic of Indonesia, as a higher education institution since 1946. Later, in 1948, when the Dutch controlled Yogyakarta, this institution was closed briefly and reopened at the end of 1949. On 19 December 1949, this higher education institution officially established itself as a national university in Indonesia under 'Universiteit Negeri Gadjah Mada' (UNGM). At that time, this university had certain faculties and delivered lectures at certain locations in the Royal Palace of Yogyakarta (Surjo, Purwanto, \& Padmo (1999). Due to the large number of students and the demand for more faculties and services, the UNGM has constructed new campus locations at Bulaksumur and Sekip. After the Dutch occupation of Indonesia ended, the UNGM was then renamed Universitas Gadjah Mada (UGM) (Universitas Gadjah Mada, 2004).

Bulaksumur and Sekip as the most integrated campus area is located on the border between Yogyakarta City and Sleman Regency. This area also plays a role in stimulating Yogyakarta City's northern development. In campus territory, UGM campus development had expanded from 85 ha in 1951 to 167 ha in 2001. Universitas Gadjah Mada's first master plan was developed in 1984-1985. The master plan in 1992 has been justified based on the 
old master plan in 1985 as following: (1) land use development, (2) university central zone development, (3) faculty group development or clustering, (4) building layout development (Universitas Gadjah Mada, 2004).

The development of Universitas Gadjah Mada (UGM) was started in the central area (Universitas Gadjah Mada, 2004). And it took place from 1951 to 2012. Within this region, there has been a multi-design approach phenomenon that has emerged in campus construction. These buildings were constructed in modern architecture as a theme, but many architects designed this campus building and introduced numerous layout designs and approaches. They range from early modern architecture to the Green Design approach. During the post-colonial Old Order of Sukarno, the first campus building, the Central Office or Kantor Pusat (1951-1956), was developed. Later on, in the post-colonial New Order of Suharto, one building was constructed, a building L7. The Library L6, or Perpustakaan Sekolah Pascasarjana UGM was erected in 1990. There was new construction in 19931994, which functions as the Grha Sabha Pramana auditorium building (GSP) (Santosa, 2018). Then, in 2011-2012, two library buildings were developed within a complex library area. Those two buildings include building library $L 1$, which is the main Library of UGM, and the other is building library L5. Therefore, at present, the campus building in the central area of UGM is as follows: Central building (Kantor Pusat), Complex Library consisting of 4 buildings, and Grha Sabha Pramana building (GSP) (Figure 1 \& 2).

Figure 1. The central area of Universitas Gadjah Mada (at the left hand) \& campus buildings (at the right hand)

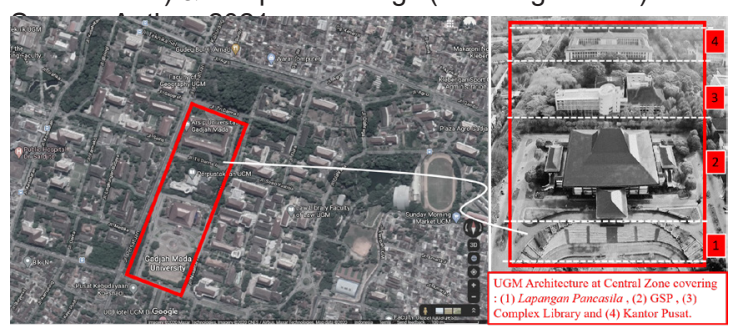

Figure 2. The Master plan of UGM at the central zone Source: Author, 2021

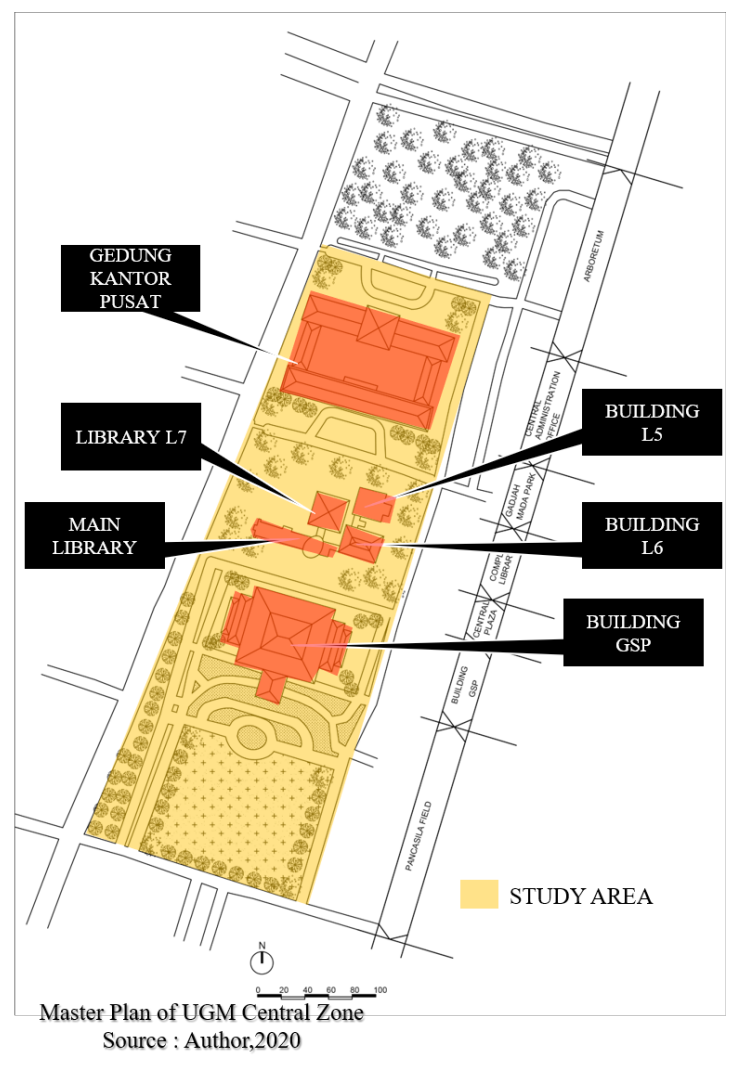

The Interpretation of Modern Movement Ideology in The Old Order, New Order, Then and Now

\section{The Modern Movement in The Post- Colonial Era of The Old Order}

The post-colonial perspectives of architecture and urbanism provide ways of thinking about constructed form and space as cultural landscapes that are internationally interconnected at once and placed specifically in space and time. Indonesia's post-colonial architecture is a brand-new architecture after independence that symbolizing the Indonesian nation. It was a time for architectural scenes that has a deep intention to build nationalism and against western hegemony.

In Indonesia, post-colonial architecture's design approach has been divided into two distinct design approaches guided by a political factor, as discussed in the literature review above. In the post-colonial Old Order of Sukarno, new architecture development promotes Indonesian-ness, modern architecture that represents national identity and avoids all sorts of colonial influences. Thus, the presidential 
ideology that time aimed to escape from the colonial trace on architectural style and create a newly independent nation-state identity after Dutch colonialism with the latest translation of Indonesian concept and identity. During his time, his ideology in creating a nationcharacter building was interpreted in many public service buildings. Obviously, in his era, the architectural styles two main architectural styles were New Indisch and Brutalist styles. The Brutalist style was primarily built in the city of Jakarta. On the other hand, in Yogyakarta city, President Sukarno's ideology was also found in the Universitas Gadjah Mada (UGM) campus building creation in the central area.

\section{1a. New Indisch Style}

New Indisch Style is a new version upgrading from the old version of Indisch architecture. Indisch Architecture or Indische Empire was the Empire building style from the development of architecture in the Netherlands that had a major influence on Batavia (Jakarta) and several other cities in Java (Faisal \& Suwantoro, 2019). It is a style of architecture between the late 19th and the 20th century before the Second World War. Its style was interpreted from Dutch architecture with a localizing method base on three key design principles such as local environment, local material, and local culture. This approach is respected in a humid tropical climate and provides the consciousness of the impacts of wind, sun, and rainfall. In addition to the design principle, the building typology was characterized by a typology of pitch roof shape to anticipate rainfall. A corridor covers the building to isolate direct heat from the sun, open plan concept to link building with the other to serve as a shaded area, building carefully design with high ventilation system consideration such as high ceiling, widely opening windows and a wide roof eave (Ardiyanto, Djunaedi, \& Suryabrata, 2015). The building erected in the post-colonial era under the style of New Indisch Architecture can be found in the Central office building of UGM.

The central office, or in a local term called Kantor Pusat building, was regarded as Indonesia's first modern architecture, which was a masterpiece design of Indonesian architect Hadinegoro in 1951-1956 (Figure 3). This building's development has relation to the political context due to under direct instruction from the first Indonesian president Sukarno.
Subroto (2016) claimed that President Sukarno directly invited architect Hadinegoro to design the central office and asked the architect to inject his political ideology into this building's design process. President's ideology was to liberate new architecture from colonial style but replace it with a modern building that could present a new face of Indonesian architecture. As a result, the architect decided to design this building by interpret Sukarno's ideology and take design inspiration from some modernism theory. Considering the philosophy of nationcharacter building, architect Hadinegoro also considered the approach of modernism, functionalism, and reductionism that President Sukarno ordered as design principles. This feature has been recognized by façade typology that shares the same characteristic as New Indisch Style, such as a pitched roof of Limasan typology, has a corridor around the building either for aesthetic purpose, produces shadow and isolate heat from the building. Besides, there is a good ventilation system management through an opening, open layout, and floorto-floor high ceiling design. Furthermore, the national character is presented in this building through the façade decoration by using façade panel of the Javanese artwork pattern. The façade panel was installed in the Kantor Pusat building's North and South view façade.

Figure 3. The Central Office - View from North Source image: https://www.ugm.ac.id/en/about, access $16 / 01 / 2021$

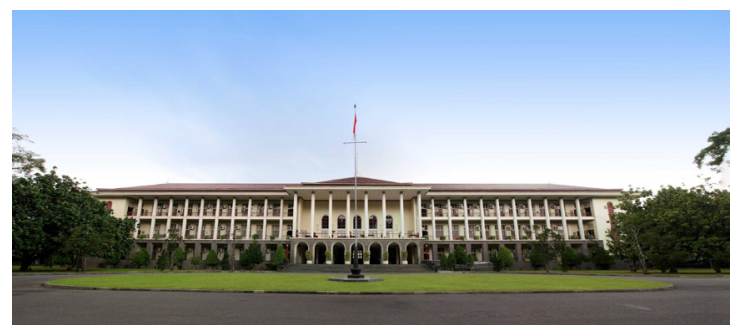

On the other hand, the authors believed that this building designer has also inspired by a Western theory of new architecture, which is called Five points of architecture by Le Corbusier (1926). However, there are fivepoint of architecture, including (1) freestanding support pillars, (2) open floor plan, (3) free façade, (4) ribbon window, and (5) Roof terrace, the architect has only interpreted 3 points from this principle due to the context of architecture. The freestanding support pillars and free façade can be found through the façade typology. The exposed and plain column, the minimized use of decoration, and a clear grid-like column 
in the South and North facade being applied as an aesthetic of this building. Besides, a simplicity of architectural elements composed by a basic geometry form such as rectangle, box, or square. Furthermore, the concept of the open layout has been applied. This inspiration defined the best offer for office construction through the basic rectangular building shape.

\section{Modern Movement in The Post-Colonial Era of The New Order}

As the previous discussion in the literature review session, the post-colonial of New Order that Suharto drove, his philosophy was to establish modern architecture and foster the understanding of the identity of traditional architecture. He aims to conserve, adopted and adapted the traditional style in modern architecture development, such as adapting traditional building typology, conception, and philosophy (Purwaningrum, 2017). This design direction is closely the same as the regionalism approach and also reflects in vernacular architecture trend but integrates contemporary construction materials and technologies. Climate and usable construction materials are the key characteristics affecting architecture. The bulk of their architectural output was portrayed in the form ofarchitectural regionalism. Many architects have perceived Suharto's new order in their approach to architecture design during that time. Consequently, there are many precedent architectures developed reflecting political order, including campus buildings, administration offices, mosques, and other public service buildings.

\section{2a. Regionalism Architecture}

As a reaction explicitly to internationalism or indirectly to modernism, regionalism is the primary critical movement. Modernism includes reverence for building materials' intrinsic qualities, structural expressiveness, and practical justifications for building-constituted forms. The regionalist approach identifies at one extreme the vernacular building modes and at the other the rediscovery of Edwin Lutyens and Frank Lloyd Wright. While it covers such a wide spectrum of attitudes, regionalism has its heart reverence for local culture, environment, and often technology. The following are the divisions observed in regionalism if one has to identify the approaches, although the limits of distinction are not too distinct, of course, vernacularism and modern regionalism(Ozkan, 1985).
The categories of vernacularism have been categorized into two methods. The conservative is one approach, while the interpretative attitude is the other. The ideals of both vernacularism styles are to bring modern and contemporary life to vernacular forms and spatial structures, differing in the way technology and society are viewed. The interpretive version of vernacularism is here referred to as neovernacularism, which has emerged for modern and contemporary functions to bring a new life to vernacular heritage. Neo-vernacularism has created less hierarchical conditions, becoming more in line with the local setting. They also helped establish a modern architecture vocabulary embedded in creating a specific culture's heritage (Ozkan, 1985).

On the other hand, modern regionalism can be used at all stages of construction activity, in contrast to vernacularism, as it derives from the monumental architecture of the past and the civil architecture to which vernacularism is confined. Contemporary regionalism may be employed within two reference types: concrete and abstract. When these buildings are lined with sacred ideals of symbolic meaning, they become much more appropriate in their current form because of the values attached to the original (Ozkan, 1985). The understanding of modern regionalism is in various types of architecture; however, one of the styles may be Brutalism's style.

\section{2b. Brutalism Style}

In British Post-War Modernism, which began from 1945 to 1985 , there are three separate stages. The first or early era began roughly between 1945 and 1960. Most buildings were essentially versions of the pre-war international style or Scandinavian influence during this time. Then the 'Massive' period came between 1960 and 1975, where rough-cast concrete predominated in chunky, asymmetrical shapes. The word 'Transitional' came from 1975 to 1985. At that time, the architect started to use brick combined with concreted and less monumental forms, stepping towards the 'Neovernacular' architecture. Brutalism is a modern type of architecture that emerged between 1945 and 1975 in Britain and other European countries. Brutalism's construction materials and structure follow functional concepts. This style of architecture of Brutalism, taken from the French béton brut '(raw concrete), 
shows the aesthetics of concrete material and has a box shape, strong, rough (without finishing), and unrefined by avoiding the use of ornament. In Indonesia, the Brutalism building style is a modern architecture style free from any architectural critic's attention. During the time of the Old Order, cement was the main raw material for infrastructure growth. Consistent with the vision of the First President of the Republic of Indonesia, Ir. Soekarno must also be portrayed by works of robust and lasting monumental architecture to create the character of a modern nation in the Guided Democracy period (1957-1965). In the New Order political era, this ideology had continued to practice. There was a broader opportunity for Indonesian architects to explore and improve their skills. In-office and campus buildings, the unfinished concrete structures of Brutalist architecture started to emerge (Han \& Kurniawan, 2018).

The architecture style of regionalism, either with vernacularism and modernism, has also been adopted in the campus building development of the UGM campus. There were three buildings erected in the post-colonial New Order era. The author believed each building had been designed to consider political ideology; however, there was no proof of any direct contact between designer and politician.

Figure 4. Building Library L7, View from North West Source image: Author,2021

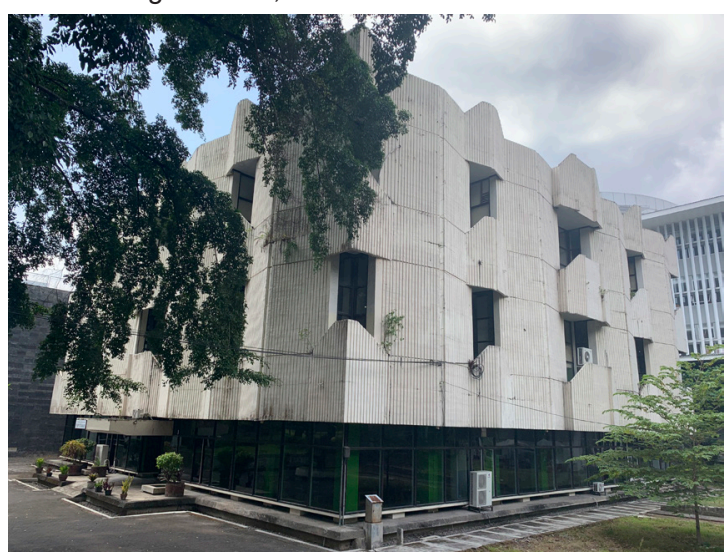

The Library L7 was the second building built in 1975 in the UGM campus area (Figure 4). This building was designed by Romo Mangun, one of the well-known Indonesian architects. President Suharto's philosophy indirectly influenced the design of his library building, and the architect integrated the idea with his design principle, which is Guna and Citra.
Guna refers to the function of the building, and Citra refers to the building's meaning. Through the façade typology and the use of material, the study determines that this building has been articulated in the context of modern regionalism, which is in the style of Brutalism architecture. Its monolithic type of architecture is distinguished by its monolithic architecture, which is built to communicate its construction with a single piece of raw concrete material and its rigid geometry form. Besides, the design of the façade has more emphasized in the horizontal and highlight with vertical strips line as the wall pattern. The building material of façade, at the 1st floor, tempered glass for wall, windows, and doors and at the 2nd and 3rd floor, the façade is solid design, every side elevation has been covered by a concrete wall, except the opening (window).

On the other hand, two campus buildings within this campus area have been built to conform to regionalism policy. These two buildings, including the L6 Library or known as Perpustakaan Sekolah Pascasarjana UGM, built-in 1990 (Figure 5), and the other building called the Grha Sabha Pramana (GSP) building auditorium, built in 1993-1994 (Figure $6)$. Both buildings have been designed for the interpretative version of vernacularism in the categories. The modern and contemporary functions have emerged from the architect of these two buildings, introducing a new version of vernacular forms and spatial structure as an approach to bringing vernacular architecture to existence with a new life. The design of this architecture had also been environmentally friendly. According to the aesthetic, both buildings were influenced by the Joglo roof style of traditional Javanese architecture. The building concept and scale were transformed from a private housing function of Joglo House to a public building function. Besides, architects have changed construction materials from traditional materials such as wood to new building materials such as cement and glass.

\section{Modern Movement in Then and Now Era - Green Architecture}

The Green Architecture concept is the philosophy, science, and style of buildings designed and built following environmental standards, also known as 'sustainable architecture' or 'green building'. Green architecture or green design is a development 
technique that minimizes damaging effects on human health and the environment. The phase of green construction starts with an intuitive knowledge of the site in all its beauty and complexity. Green architecture's main aim is to be completely sustainable, including ventilation systems designed for effective heating and cooling, energy-efficient lighting and appliances, water-saving plumbing fixtures, landscapes designed to optimize passive solar energy, minimal harm to the natural environment, renewable energy sources such as solar power or wind power, non-synthetic, non-toxic materials (Ragheb et al., 2016). Therefore, green architecture is a design strategy applied to attain a target of sustainable design. Construction and lifelong activity ensure that the ecosystem is as safe as possible while representing the most effective and least destructive use of land, water, energy, and resources. Green design is an application term in buildings for environmentally friendly technologies. In its design process, green architecture calculating the relationship between building orientation and the surrounding environment, the sun path, the wind direction, site management, and waste management. This design trend is more challenging to creativity, design innovation, and design efficiency (Hanum \& Murod, 2014).

In the following century, after the New Order's political era came to an end, the architectural discourse called as then and now began to show new faces. In this era, modern architectures have two directions of a design approach. One direction was the adaptation of vernacular architecture, and minimalist design was the other direction. The minimalist design has been widely spread in new architecture development. As a result, this style has also reached the library buildings of UGM, which are building L1 and L5. The Library L1 or other name of the Central Library (Figure 7) and building L5 were planned and constructed in 2011-2012 (Figure 8). to adapt the approach to green buildings. Both library buildings' typology has the same characteristic of minimalist architecture that interconnected the international style with the localizing method. Green architecture was a design approach that is adopted during the design process of both buildings.
Figure 5. Building Library L6 View from East Source image: Author,2021

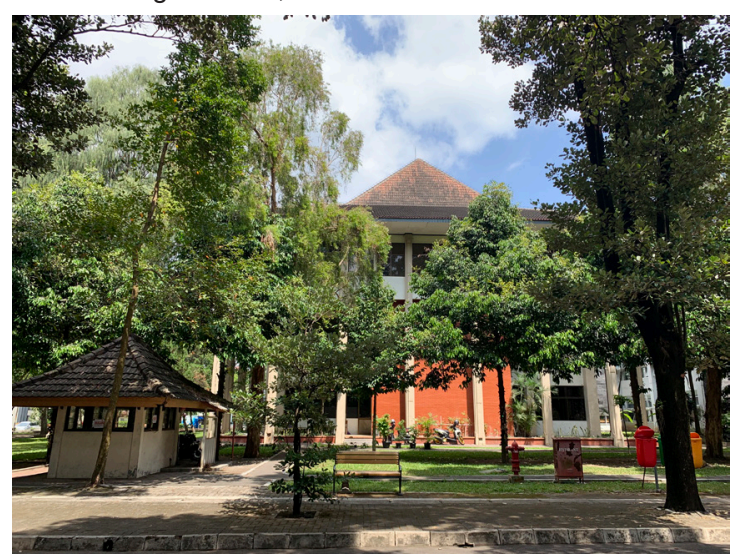

Figure 6. Auditorium building Grha Sabha Pramana (GSP) view from South

Source image: Author,2021

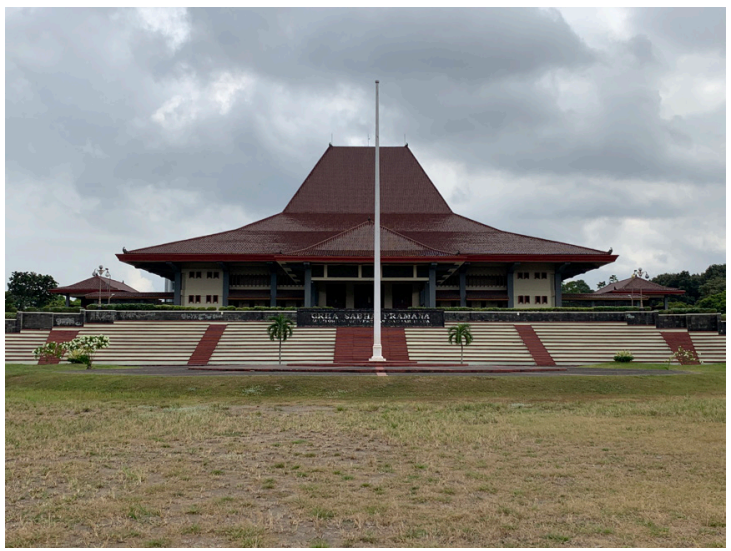

Figure 7. UGM Central Library (L1) View from South Source image: Author, 2021

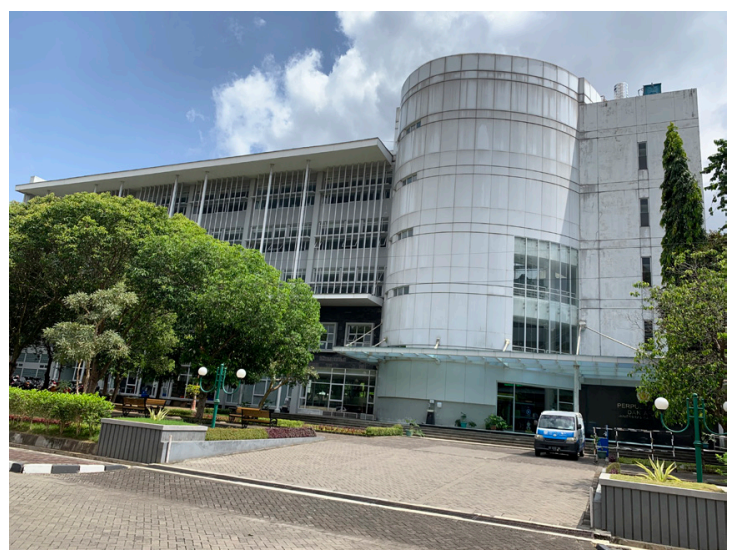

The UGM central library (L1) has applied the ecological concept well through several strategies. Also, the design of this building has been inspired by the principle of Sim Van der Ryn with a parameter of ecological accounting, design with nature, and making nature visible. The building has been aimed at achieving green design by many techniques 
in the Ecological Accounting criteria, such as maximizing green open space, using green roofing, minimizing the allocation of air conditioning, using natural materials, and optimizing natural lighting air circulation. The building has applied construction materials suitable to the construction orientation and purpose of each space in the design parameter with nature. In the north and south view of this building façade, both horizontal and vertical external shading systems have been applied. These shading systems provide the natural lighting and air ventilation in the building. This building has applied many glass windows to engage the reading area with an outdoor view in the parameter of making nature accessible. Furthermore, an atrium roof was located in the main lobby of this building to allow natural light into the library building and to see the natural views of the sky. Such characteristics save energy costs and make the indoor atmosphere lively (Adi, 2017).

The L5 Library, on the other hand, is one of the library buildings in the UGM library complex. This building was designed with the central library UGM in the same year as the building L1. Because of the typological features of this structure, such as the building typology, the application of construction material used vertical ventilation, glass window following the building orientation North-South, whereas the solid wall with some glass box was used in the East-West to let natural light into the building, and all the materials are used in the same method. Therefore, the author believes that the green design method was also adopted by building L5. Both buildings were built in the campus area, taking into account their environmental effects and promoting renewable energy sources. Figure 8. Library L5 View from View from North
Source image: Author,2021

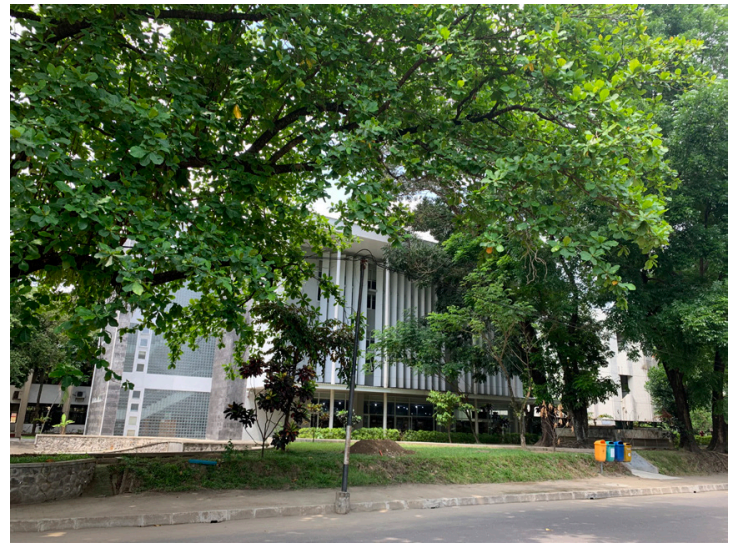

Based on the discussion above, this current study can summarise the finding as shown in figure 9 below. Figure 9 briefly illustrates the overview of the development timeline of a campus building with detail of the construction year and position in the political period, the name of a building, and the architectural styles.

\section{Conclusion}

Universitas Gadjah Mada (UGM) was founded in the post-colonial period as a national university. The central zone was the initial zone of this campus development. The study found that there was a process of the evolution of the modern architecture design movement. This research also showed that modern architectures' design resulted from some architects' philosophy and that a political ideology also influences each development

Figure 9. Summary of campus building development timeline Source image: Author,2021

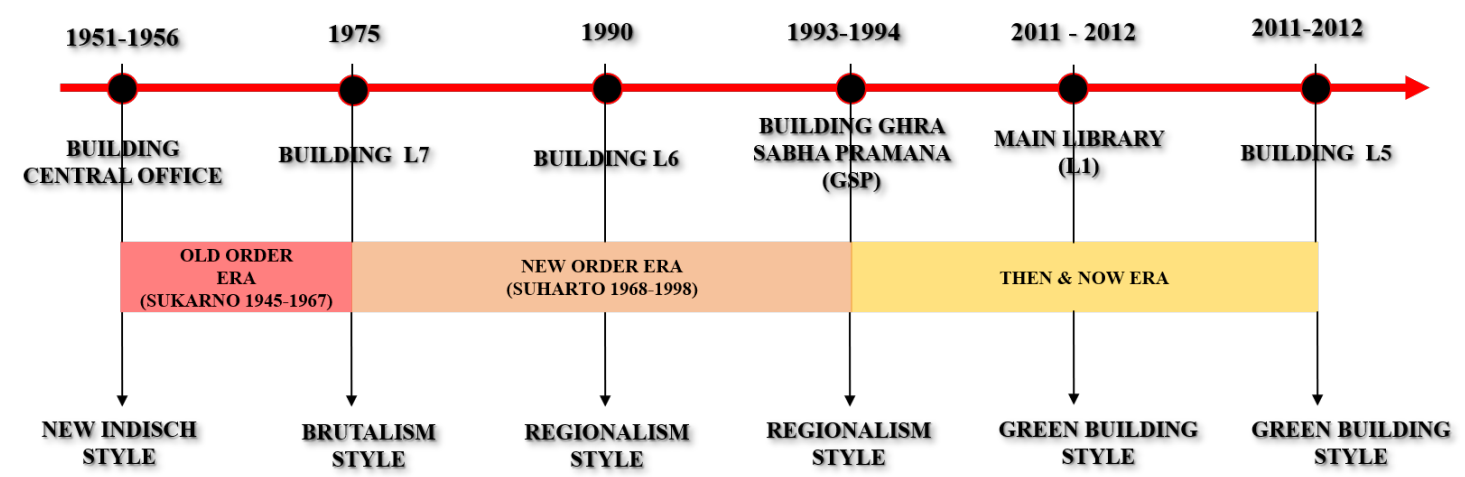


process. Due to the discussion on case studies, the research found that in the context of UGM campus building development, the ideology of each political era and cultural and social context has been interpreted into different design approaches and architecture styles.

In the post-colonial era of the Old Order, the architect has translated political ideology into architecture in the New Indisch Style form. Meanwhile, in the following post-colonial era of the New Order, architects have translated political ideology into architecture in the regionalism style. One regionalism style was modern regionalism which translated into a brutalist style. And another was vernacularism which translated into a regionalism architecture inspired by a traditional Javanese house. In the following political period that this study called as Then and Now era, the architecture production in that period didn't result from the political factor. Still, the architect would rather follow the architecture trend when the green design influenced the architecture style and solution to architecture growth of 21 st century.

Therefore, the establishment of this postcolonial university has a goal to build a national university for educational purposes and attempt to construct a new typology of architecture. This also contributed to the urban landscape that distinguishes post-colonial Indonesia architectures from their colonial forms and opens up new development. On the other hand, the study concludes that the choice of architecture styles and approach during the design process has been considered by individual architects of each building with high consideration to context and integrated idea follow the evolution of architectural trends. For example, the architectural development in the 20th century was the time after the colonial period. At that time, architectures have more likely been desired to use as political tools to express the country's new face. Thus, the architectural design principle was focused more on culture and identity. The regionalism architecture approach, either modernism and vernacularism, became popular for the architecture trend in the post-colonial era. That's why the style of New Indisch, Brutalism, and Regionalism architecture was adopted in campus building design in the 20th century. Meanwhile, in the 21st century, sustainable architecture became a popular architecture trend. This trend is the best solution to the issue of economy, ecology, and culture. Therefore, the two additional library buildings have been developed in the green architecture style.

\section{References}

Abdu, M., \& Syahid, A. (2018). Translating Modern Ideas into Postcolonial Mosque Architecture in Indonesia. https://doi. org/10.24853/ijbesr.2.1.39-46

Adi, A. R. (2017). Kajian konsep ekologis pada gedung perpustakaan pusat UGM. ATRIUM Jurnal Arsitektur, 3(1), https://doi. org/10.21460/atrium.v3i1.67.

Ali, F. A. (2018). The Influence of Le Corbusier On the emergence of the Aesthetic Values in the Modern Architecture of Cyprus. Journal of Contemporary Urban Affairs, 2(1), 1-12. https://doi.org/10.25034/ ijcua.2017.3651

Ardiyanto, A., Djunaedi, A., Ikaputra, S., \& Djatmika, A. (2014). The concept of modern dutch colonial architecture to the development of Javanese architecture. DIMENSI (Journal of Architecture and Built Environment), 41(1). https://doi. org/10.9744/dimensi.41.1.37-42

Ardiyanto, A., Djunaedi, A., \& Suryabrata, J. A. (2015). The Architecture of Dutch Colonial Office in Indonesia and the Adaptation to Tropical Climate. International Journal of Scientific and Research Publications, 5(4). www.ijsrp.org

Faisal, I., \& Suwantoro, H. (2019). The Study of Indisch Architecture Development as an Effort in Preserving the Heritage of Colonial History in Medan. Budapest International Research and Critics Institute (BIRClJournal) : Humanities and Social Sciences, 2(4), 207-214. https://doi.org/10.33258/ birci.v2i4.583

Han, N. N., \& Kurniawan, K. R. (2018). Brutalism: The Socio-Political and Technological Effect on Post-colonial Modern Architecture in Indonesia. E3S Web of Conferences, 65. https://doi. org/10.1051/e3sconf/20186501004

Hanum, M., \& Murod, C. (2014). Green architecture and energy efficiency as a trigger to design creativity: a case study to Palembang city library. Journal of Architecture \& Environment, 13(2). https:// dx.doi.org/10.12962/j2355262x.v13i2. a877 
Hanum, N. N., Lukito, Y. N., \& Kurniawan, K. R. (2020). Concrete: Politics in the Development of Modern Architecture in Indonesia. IOP Conference Series: Earth and Environmental Science, 452(1). https:// doi.org/10.1088/1755-1315/452/1/012009

Hebbert, M. (2018). The Campus and the City-a Design Revolution Explained.

Ismudiyanto \& Santoso, H. S. (2016). Gedung Pusat Universitas Gadjah Mada (T. Y. W. Subroto, Ed.). Gadjah Mada University Press.

James-Chakraborty, K. (2014). Beyond postcolonialism: New directions for the history of nonwestern architecture. Frontiers of Architectural Research, 3(1), 1-9. https://doi.org/10.1016/j. foar.2013.10.001

Kusno, A. (2000). Behind the Postcolonial: Architecture, Urban Space and Political Cultures in Indonesia (1st ed.). Routledge.

Kusno, A. (2012). Zaman Baru Generasi Modernis: Sebuah Catatan Arsitektur (Budiman Manneke, Ed.). Ombak .

Loanoto, S. Y., \& Hidayahtun, M. I. (2019). Wastu Citra as an Indonesia Regionalism Local Wisdom (Phenomenology Studies from Butet's House). International Journal of Architecture and Urbanism, 03(01), 6980.

Nia, H. A., \& Rahbarianyazd, R. (2020). Aesthetics of modern architecture: A semiological survey on the aesthetic contribution of modern architecture. Civil Engineering and Architecture, 8(2), 66-76. https://doi.org/10.13189/cea.2020.080204

Ozkan, S. (1985). Exploring Architecture in Islamic Cultures 2: Regionalism in Architecture. In R. ; M. K. I. Powell (Ed.), Introduction Regionalism within Modernism (pp. 8-16). Concept Media Pte Ltd for The Aga Khan Award for Architecture.

Peters, M. A. (2019). Manifesto for the postcolonial university. Educational Philosophy and Theory, 51(2), 142-148. Routledge. https://doi.org/10.1080/00131857.2017.13 88660

Purwaningrum, D. A. (2017). Long road to identity: Critical Study of Contemporary Nusantaran Architecture. https://mbuseru. wordpress.com/2013/06/07/mbuseru-

Ragheb, A., El-Shimy, H., \& Ragheb, G. (2016). Green Architecture: A Concept of Sustainability. Procedia - Social and Behavioral Sciences, 216, 778-787. https:// doi.org/10.1016/j.sbspro.2015.12.075
Santosa, H. (n.d.). Sejarah singkat grha sabha pramana UGM dari khazanah arsip Universitas Gadjah Mada. Gadjah Mada University Press.

Surjo, D., Purwanto, B. A., \& Padmo, S. (1999). Dari revolusi ke reformasi: 50 tahun Universitas Gadjah Mada. Universitas Gadjah Mada.

Universitas Gadjah Mada. (2004). Rencana Induk Pengembangan Kampus (RIPK) 2005-2015.

Wiryomartono, B. (2013). Soejoedi and architecture in modern Indonesia: a critical post-colonial study. International Journal of Architectural Research Bagoes Wiryomartono Archnet-IJAR, 7. 